\title{
Is India Really Competing with China on a Macro Economic Base
}

\author{
Desti Kannaiah $^{1} \&$ Uma T. ${ }^{2}$ \\ ${ }^{1}$ School of Business, James Cook University, Singapore \\ ${ }^{2}$ Research Scholar, Bharathiyar University, Coimbatore, India \\ Correspondence: Desti Kannaiah, School of Business, James Cook University, Singapore. E-mail: \\ kannaiah.desti@jcu.edu.au
}

Received: September 5, 2016

Accepted: October 5, 2016

Online Published: October 25, 2016

doi:10.5539/ijef.v8n11p150

URL: http://dx.doi.org/10.5539/ijef.v8n11p150

\begin{abstract}
Macroeconomics has been aptly defined as "the study of the major economic 'totals' or aggregates-- total production (GNP), total employment and unemployment, the average price level of all goods and services, the total money supply, and others" (Gordon, 1978). The word macro is derived from the Greek word macros meaning large

The economy of India has seen rapid growth in recent years. Spurred by good domestic demand, steady and significant reforms, lower crude prices and increased skilled labor India is the fastest growing economy among the BRICS nations. Another Asian country which is also in the fast lane with respect to macroeconomic growth is China. China's growth has primarily been attributed to a sharp sustained increase in productivity accompanied by increase in capital accumulation, improved infrastructure and cheap labor force (Hu \& Khan, 1997).

Both India and China have emerged as significant forces in the global economy over the last two decades. Both countries are geographically very large and have a huge population. Both countries have also achieved remarkable rates of economic growth and poverty reduction since 1980,with India doubling its per capita GDP and China posting a seven fold increase in its per capita GDP (Bosworth \& Collins, 2008). A PWC report titled "World in 2050" predicts China and India to be world leading powerhouse economies by 2050.
\end{abstract}

Keywords: economy, GNP, BRICS, growth

\section{Literature Review}

The impact of specific variables on the macroeconomic developments of countries has been of interest to researchers for a long time. Researchers have especially been fascinated by the impact of specific macroeconomic variables like interest rates, inflation, money supply and exchange rates on the economic growth of developing economies. A study of the empirical relations between interest rates and macroeconomic growth in emerging economies like Brazil,Mexico, Korea,Argentina and Philippines from 1994-2000 highlighted the importance of interest rates in determining business cycles (Neumeyer \& Perri, 2001). The relationship between inflation and economic growth in Bangladesh, India, Pakistan and Silence by Mallik and Chowdhury (2001) found evidence of a long-run positive relationship between GDP growth rate and inflation and between inflation and economic growth. A comprehensive study on the impact of exchange rates on economic growth of 183 developing countries found that less flexible exchange rate regimes are associated with slower growth, as well as with greater output volatility. (Yeyati \& Sturzenegger, 2003).

In the last decade researchers have shown special interest in the economic growth of the two Asian giants-India and China. A comparative analysis of India and China's growth story by Huang and Hanna (2003) emphasizes the radically different development strategies followed by India and China; it stresses the key role played by homegrown entrepreneurship of India over the FDI dependent approach of China in long term development. Lin and Yunhiu (2005) further analyzed the relationship between money supply, inflation and economic growth of China .They concluded that while in the long run money and economic growth boost each other, inflation obstructs economic growth. A detailed analysis by Basu and Maertens (2007) traced the phenomenal growth story of India from the 1950s till 2005.The study shed light on the remarkable GDP growth, imports and exports of India also outlining the reasons for its emergence as a powerful nation in the global economy. Another interesting study on the impact of real exchange rates on economic growth showed that undervaluation of currency stimulates economic growth (Rodrik, 2008). A study on the impact of globalization on economic 
growth found that globalization has a stabilizing effect on individual economies and promotes economic growth. (Mishkin, 2009). Studies on financial development and economic growth has also been an area of keen interest. An analysis on the financial development and economic growth of India incorporating stock market development found that while financial development and economic growth are bidirectional, economic growth and stock market development are unidirectional (Pradhan, 2011). A similar study on the relationship between financial development and economic growth of China concluded that most traditional indicators of financial development are positively associated with economic growth (Zhang,Wang, \& Wang, 2012).

Though studies have explored the macroeconomic developments in various emerging economies including India and China individually, studies involving a comparative analysis of macroeconomic developments of India and China are relatively limited. Both India and China have become significant powers in the global economy only over the last decade. Both countries are in Asia, are geographically very vast and together account for more than one third of the world's population. Though their growth path has been very different, they have both consistently maintained a growth rate exceeding $6 \%$ over the last decade and are predicted to become leading world economies over the next two decades which makes their comparison very compelling and relevant in the current global economic scenario.

\section{Objectives}

To identify the macroeconomic indicators of India and China for a span of ten years (2006-2015).

To find the significant difference between India and China with respect to macroeconomic indicators.

\section{Hypothesis}

There is no significant difference between India and China with respect to macro economic development in the span of 10 years from 2006 to 2015.

\section{Research Methodology}

The study of based on pure secondary data collected from websites of RBI, Bombay Stock Exchange, People's bank of China, Shanghai stock exchange and Data monitor for the span of 10 years from 2006 to 2015.After collecting secondary data for the adequate number of years the researcher used paired t test for the seven macroeconomic indicators, ie, exchange rates, short term interest rates, money supply (M1), money supply (M2), gross domestic product, consumer price index and stock index values of both India and China respectively. Besides these Karl Pearson's coefficient of correlation, measures of central tendency and measures of dispersion are subsequently exploited to identify the significant difference.

Table 1. Analysis and discussion

\begin{tabular}{llcccc}
\hline & & Correlation & Sig. & $\mathrm{t}$ & Sig. (2 tailed) \\
\hline Exchange Rates & INDIA \& CHINA & -.760 & .011 & 16.482 & .000 \\
Interest rates & INDIA \& CHINA & .854 & .022 & 16.176 & .000 \\
Money Supply (M1) & INDIA \& CHINA & .990 & .000 & -7.400 & .000 \\
Money Supply (M2) & INDIA \& CHINA & .996 & .000 & -6.462 & .000 \\
GDP & INDIA \& CHINA & .696 & .026 & -6.440 & .000 \\
CPI & INDIA \& CHINA & .983 & .000 & .577 & .578 \\
Stock Index & INDIA \& CHINA & .222 & .537 & 10.098 & .000 \\
\hline
\end{tabular}

From the above table it is found that the mean exchange rate of one US dollar to the Indian Rupee is Rs 50.82 and the mean exchange rate of one US dollar to the Chinese Yuan is 6.75 Yuan. The standard deviation for these countries is found to be 7.97 and 0.62 respectively. The correlation coefficient between the exchange rates of India and China is $\mathrm{r}=0.760, \mathrm{p}=0.011$ are statistically significant at $5 \%$ level. Similarly the $\mathrm{t}$ value for the significant difference in the exchange rate of India and China is found to be $16.482, \mathrm{p}=.000$ are also statistically significant at 5\% level. This implies that as far as exchange rates of India and China are concerned, they are negatively related and are in opposite direction. The significant $t$ value indicates the existence of large scale difference between the exchange rates of India and China for the span of 10 years.

The mean short term interest rate of India $=7.89 \%$ and the mean short term interest rate of China $=3.52 \%$. The standard deviation for these countries is found to be 1.62 and 1.20 respectively. The correlation coefficient between the short term interest rates of India and China is $r=0.854, p=0.002$ are statistically significant at $5 \%$ level. The $\mathrm{t}$ value for the significant difference in the short term interest rate of India and China is found to be 
$16.176, p=.000$ are also statistically significant at $5 \%$ level. This implies that the interest rates of India and China are positively related and are in the same direction. The significant $t$ value indicates the existence of large scale difference between the short term interest rates of India and China for the span of 10 years.

The money supply (M1) in India averaged 15316.29 INR billion and money supply (M1) of China averaged 23967.84 CNY billion. The standard deviation for these countries is found to be 5031.91 and 8612.32 respectively. The correlation coefficient between the money supply (M1) of India and China is $r=0.990, p=0.000$ are statistically significant at $5 \%$ level. The $t$ value for the significant difference in the money supply (M1) of India and China is found to be $7.4, p=.000$ are also statistically significant at $5 \%$ level. This implies that the money supply (M1) of India and China are positively related and they move in the same direction. The significant $t$ value indicates the existence of large scale difference between the money supply (M1) values of India and China for the span of 10 years.

The average value of money supply (M2) in India is 15620.18 INR billion and the average value of money supply (M2) of China is 23967.84 CNY billion. The standard deviation for these countries is found to be 5142.97 and 34824.35 respectively. The correlation coefficient between the money supply (M2) of India and China is $\mathrm{r}=0.996, \mathrm{p}=0.000$ are statistically significant at $5 \%$ level. The $\mathrm{t}$ value for the significant difference in the money supply (M2) of India and China is found to be 6.4, p=.000 are also statistically significant at $5 \%$ level. This implies that the money supply (M2) of India and China are positively related and they move in the same direction. The significant value indicates the existence of large scale difference between the money supply (M2) values of India and China for the span of 10 years.

The mean value of real gross domestic product (GDP) of India is 1675.30 INR billion and the mean value of real gross domestic product of China is $4331 \mathrm{CNY}$ billion. The standard deviation for India and China is found to be 157.67 and 1408.80 respectively. The correlation coefficient between real GDP of India and China is $\mathrm{r}=0.696$, $\mathrm{p}=0.026$ are statistically significant at $5 \%$ level. The $t$ value for the significant difference in the real GDP of India and China is found to 6.4, p=.000 is also statistically significant at 5\% level. This implies that the real GDP of India and China are positively related and they move in the same direction. The significant $t$ value indicates the existence of large scale difference between the real GDP values of India and China for the span of 10 years.

The mean value of consumer price index (CPI) of India is 106.17 and the mean value of consumer price index of China is 102.12. The standard deviation for India and China is found to be 27.93 and 9.25 respectively. The correlation coefficient between CPI of India and China is $r=0.983, p=0.000$ are statistically significant at $5 \%$ level. The t value for the significant difference in the CPI of India and China is found to $0.577 \mathrm{p}=.578$ is not statistically significant at 5\% level. This implies that the CPI of India and China are positively related and they move in the same direction. The $t$ value is not significant which indicates that there is no large scale difference between the CPI values of India and China for the span of 10 years.

The mean value of the Bombay Stock Exchange Sense in India is 18035.4 and the mean value of the Shanghai Stock Exchange Composite Index in China is 2748.5. The standard deviation for India and China is found to be 4898.94 and 767.79 respectively. The correlation coefficient between value of the major stock indexes of India and China is $\mathrm{r}=0.222, \mathrm{p}=0.537$ are not statistically significant at $5 \%$ level. The $\mathrm{t}$ value for the significant difference in the value of the major stock indexes of India and China is found to $10.09, \mathrm{p}=.000$ is statistically significant at 5\% level. This implies that the value of the major stock indexes of India and China have a weak positive correlation. This means that changes in the Sensex are not strongly correlated to changes in the SSE Composite Index. The significant $t$ value indicates the existence of large scale difference between the value of the major stock indexes of India and China for the span of 10 years.

Therefore the null hypothesis is rejected. The data shows that there is a significant difference between India and China with respect to macro-economic development in the span of 10 years from 2006 to 2015.

\section{Findings}

The exchange rate of the dollar to the rupee has depreciated while the dollar to Yuan has appreciated over the span of 10 years, 2006-2015. The reason for the significant difference and negative correlation between both currencies is that the Indian Rupee is on a managed float and is determined mostly by market forces, while the Chinese Yuan, is controlled by strict government policies. Though the Yuan is also under a managed float and trading band for the Yuan has been gradually relaxed to $+/-2 \%$ in 2014 from $+/-0.3 \%$, the Chinese government still regulates trading activity and controls the movement of the Yuan in the foreign exchange market.

China's interest rates are much lower than that of India. This is in spite of China having an inflation rate which is almost as high as India. The main reason for the low interest rates is that China's growth model is primarily 
based on fixed investment. In order to boost investment based growth, the Chinese government has consciously followed a policy of fixing lending rates well below the country's growth rate and inflation rate. This makes borrowers of money benefit at the cost of savers. Indian interest rates are fixed by the RBI after considering a balance between growth and inflation. The significant difference in interest rates between both countries is due to a conscious policy of maintaining low interest rates.

China's money supply (M1 and M2) is significantly higher than India. As per world bank data China's M2 to GDP ratio is around $190 \%$, which is phenomenally higher than India (77\%), USA (89\%) or the UK (138\%). One of the main reasons for this is the burgeoning foreign exchange reserves and the current account surpluses of China. The domestic growth of China is spurred by the Chinese banks releasing an amount of Yuan equivalent to the amount of foreign exchange reserves collected. This huge internal stimulus coupled with low interest rates and increased lending is the backbone of the Chinese growth story. The Chinese government has also been accused of actually printing more money to achieve the huge injection of capital and money supply. The money supply in India is regulated by a series of mechanisms like increase or decrease of repo rates, statutory liquidity ratio; cash reserve ratio and change in other monetary policies.

The GDP of China and India also shows a significant difference. The service sector share accounts for a huge share in India's GDP.A depreciating rupee and falling prices of oil in recent times have also helped in making Indian exports more competitive. The significant difference between India's and China's GDP is because the China's GDP primarily comes from export of manufactured products. The cheap labor force of China combined with conscious devaluation of its currency has kept Chinese goods competitive in foreign markets. This has helped to increase China's GDP.

There is no significant difference between India and China's inflation. Both countries are developing economies and a relatively high inflation is quite common in growing economies.

The stock markets of India and China also show a significant difference. China's stock markets attract relatively less foreign investment due to the restrictions imposed by the Chinese government. Besides this government control still plays a major role in Chinese stock markets controlling and regulating buying and selling. The stock market of China is also heavily influenced by small investors which lead to the market being heavily dominated by whims and fancies of buyers resulting in a near gambling scenario. India's stock markets attract more foreign investment due to the country's high growth rates and the open nature of its markets. Indian stock markets are more synchronous to foreign markets unlike the Chinese stock markets.

\section{Conclusion}

India has been lagging behind China in terms of growth rate over the last decade. The Chinese growth story based on enhancing investment and encouraging exports worked very well for the country over the last decade making its GDP and growth rate shoot up and making it a formidable power in the Asian growth story. The foundation of the Indian growth story is based on the twin theories of stimulating domestic demand and attracting foreign investment. A stable government at the centre and an investment friendly environment combined with the ability of the government to maintain a right balance between avoiding over interference while exercising prudent control has encouraged foreign investment. The Indian economy has moved like the proverbial tortoise and has slowly sneaked past China over the last year. The Chinese government is working ardently towards increasing its domestic consumption and promoting growth. The excessive government regulation means that the growth of China is happening in a very controlled and simulated environment. The achievement of long term sustainable growth while continuing to maintain strict control over macroeconomic variables presents a huge challenge for China. The Indian elephant has stolen a march over the Chinese dragon and continues to roar. A radical transformation in policies will be required for China to get back to its growth rates over the last decade.

\section{References}

Basu, K., \& Maertens, A. (2007). The pattern and causes of economic growth in India. Oxford Review of Economic Policy, 23(2), 143-167. http://dx.doi.org/10.1093/icb/grm012

Bosworth, B., \& Collins, S. M. (2008). Accounting for growth: comparing China and India. The Journal of Economic Perspectives, 22(1), 45-66. http://dx.doi.org/10.1257/jep.22.1.45

Gordon, R. J. (1978). Macroeconomics. Boston: Little, Brown and Company.

Hu, Z. F., \& Khan, M. S. (1997). Why is China growing so fast? Staff Papers, 44(1), 103-131. http://dx.doi.org/10.2307/3867499 
Huang, Y., \& Khanna, T. (2003). Can India overtake china? Foreign Policy, (137), 74. http://dx.doi.org/10.1093/oxrep/grw022.

Levy-Yeyati, E., \& Sturzenegger, F. (2003). To float or to fix: Evidence on the impact of exchange rate regimes on growth. The American Economic Review, 93(4), 1173-1193. http://dx.doi.org/10.1257/000282803769206250

Lin, L., \& Yunhui, J. (2005). Money Supply, Inflation and Economic Growth of China-The Experimental Analysis Based on Cointegration Analysis. Statistical Research, 3, 2.

Mallik, G., \& Chowdhury, A. (2001). Inflation and economic growth: Evidence from four south Asian countries. Asia-Pacific Development Journal, 8(1), 123-135.

Mishkin, F. S. (2009). Globalization, macroeconomic performance, and monetary policy. Journal of Money, Credit and Banking, 4l(s1), 187-196. http://dx.doi.org/10.1111/j.1538-4616.2008.00204.x

Neumeyer, P. A., \& Perri, F. (2005). Business cycles in emerging economies: The role of interest rates. Journal of Monetary Economics, 52(2), 345-380. http://dx.doi.org/10.1016/j.jmoneco.2004.04.011

Pradhan, R. P. (2011). Financial development, growth and stock market development: The trilateral analysis in India. Journal of Quantitative Economics, 9(1), 134-145.

PWC.

Retrieved

from https://www.pwc.com/gx/en/issues/the-economy/assets/world-in-2050-february-2015.pdf

Rodrik, D. (2008). The real exchange rate and economic growth. Brookings Papers on Economic Activity, 2008(2), 365-412.

The World Bank. (n. d.). Retrieved from http://data.worldbank.org/indicator/FM.LBL.MQMY.GD.ZS

\section{Copyrights}

Copyright for this article is retained by the author(s), with first publication rights granted to the journal.

This is an open-access article distributed under the terms and conditions of the Creative Commons Attribution license (http://creativecommons.org/licenses/by/4.0/). 